\title{
THE IMPACT OF INTERNAL CONTROL ON PERFORMANCE OF SMALL AND MEDIUM-SIZED ENTERPRISES IN AN EMERGING ECONOMY
}

\author{
Nguyen To Tam* and Le Anh Tuan \\ Faculty of Economics and Management, \\ Electric Power University, Vietnam
}

\begin{abstract}
This research studied the impact of internal control on financial performance of small and medium-sized enterprises (SMEs) in an emerging economy. The studying framework was derived from the Agency Theory to examine the relationship between internal control and organizational performance in SMEs. The paper used a survey and non-probability sampling and applied regression analysis to assess this effect on SMEs in Hanoi, Vietnam. Internal control consisted of five elements (including control environment, risk assessment, control activities, information and communication systems, and monitoring activities) by COSO. SME's performance was measured by ROA primarily. This research analyzed data using SPSS and SmartPLS softwares. Using a sample of 94 respondents, the results show that the control environment which is a dimension of internal control has a positive influence on the performance of SMEs in this case. Other dimensions of internal control that are control activities, information and communication system, risk assessment, and monitoring activities showed insignificant impacts on performance of SMEs but the results still give some meaningful insights for SMEs in Vietnam. The results of this paper provide practical insights on the role of internal control for researchers and business managers.
\end{abstract}

Keywords: internal control, performance, small and medium-sized enterprises

\section{ARTICLE INFO}

\section{Article History:}

Received: 6 January 2021

Accepted: 19 April 2021

Published: 31 August 2021

* Corresponding Author: Nguyen To Tam. E-mail: tamnt@epu.edu.vn 


\section{INTRODUCTION}

Small and medium-sized enterprises (SMEs) account for a large number of businesses in the world and have important contributions to employment and economic stability. SMEs have inherent advantages of size and flexibility. They have the ability to innovate, diversify their products and services, and contribute significantly towards job creation (Hussain et al., 2006). SMEs are the "backbone of Asia's economy" and are a major driving force in Asia. SMEs account for $97 \%$ of the total number of businesses and $69 \%$ of employment in Asia, but their contribution is limited to an average of $41 \%$ gross domestic product per country (ADB, 2020). SME's distinctive features are low investment capital, quick turnover, and simple organizational structure. Accordingly, SMEs possess dynamic adaptabilities and have the capability of penetration in niche markets and industries with high a profit. SMEs have been known as playing an important role in any country (ADB, 2020; Pham, 2017).

Vietnam is an emerging economy (OECD, 2019), in which SMEs have an important role in contributing to the national economy (Kokko \& Sjöholm, 2005). SMEs in Vietnam are enterprises that do not exceed 50-200 employees who have social insurance and the total turnover of a year that does not exceed 50-200 billion Vietnam Dong (8 million USD approximately) or the total capital does not exceed 20 - 100 billion Vietnam Dong (4 million USD approximately) (Government, 2018). In recent years, the number of SMEs has been growing rapidly that has created a lot of jobs for the Vietnamese labor market. In Vietnam, SME is a dominated form of enterprise that accounts for $97.2 \%$ of total businesses in Vietnam in 2018 and employed over $38 \%$ of labor the force. SMEs mainly focus on traditional businesses and mostly in low-tech industries. Innovation and internationalization are keys to enhancing SME efficiencies and to boost Vietnamese enterprise's productivities (ADB, 2020). The success of SMEs has played a very important role in the growth of the Vietnamese economy and the sustainable development of SMEs is an important factor to ensure the stability and the development in terms of economic growth and employment of labor (Tran et al., 2008; ADB, 2020).

SMEs are now actively participating in the global network in the volatile and unpredicted business environment. These also face high 
potential risks, such as lack of resources to cope with the business risks in comparison with large enterprises in emerging countries (Wang \& Ding, 2019). This makes performance measurement and monitoring as key issues for SMEs' management (Sharma et al., 2005; Suárez, 2016). To enhance SMEs' performance, several management practices have been studied and have proved their relationship and usefulness. Among these tools, is an internal control system which is a necessary and effective tool for evaluating business performance, operational effectiveness, and investment efficiency. Internal control helps enterprises to prevent risks, ensure the quality of information and compliance with laws and regulations. Internal control provides a reasonable assurance that helps an organization to gain its goals (ACCA, 2016). Internal control can be used as a performance assessement tool of SMEs and its role has been confirmed in several studies (Shanmugam et al., 2012), (Kamau, 2016).

Researches of SMEs in Vietnam have mainly focused on characteristics and development of SMEs. Nonetheless, internal control in SMEs has been seen to be effective at a medium level (Thuan \& Cuong, 2020). The positive influence of internal control and performance has been shown in Vietnamese construction enterprises (Tuan, 2020), yet this issue has not been addressed for SMEs in detail. Several authors have studied the role of internal control in business and have stressed the role of internal control in SMEs. However, its impact on performance has not been reported (Thuy, 2016). Therefore, this research aimed to assess the elements of internal control (COSO model) that influence SMEs' performance. This knowledge will useful for owners and CEOs of SMEs to use internal control relevantly for business management.

This research aimed to: (1) examine the relationship between internal control of SMEs and SMEs' performance; (2) identify the impact level of internal control on SMEs' performance; (3) provide recommendations to improve the effectiveness and efficiency of internal control implementation in SMEs. 


\section{LITERATURE REVIEW}

\section{SMEs' Performance}

Performance is a general economic indicator reflecting the efficiency of resource usage such as material, human, and capital resources to get the organizational results. In general, performance is obtained by valuing of input and output of a business in a given period. The performance of SMEs is evaluated by the contributions to the related parties such as owners, customers, public, and government (Aminu \& Shariff, 2015).

Trinh and Thanh (2017) showed that the performance of SMEs was inferior in comparison with large enterprises in terms of labor utilization and profitability. And SMEs' performance, generally, are reflected mainly through financial indicators. There are several indicators for measuring performance, in which, ROA (return on assets) or ROI (return on investment) are used frequently in many studies (Kamau, 2016; Nyakundi et al., 2014; Maelah \& Yadzid, 2018).

An SME usually used a performance measurement system to measure and monitor its performance systematically. In general, both financial and non-financial indicators have been integrated into the performance measurement system, in which ROA has been the most commonly used indicator to measure the performance of SMEs in India and Germany (Sharma et al., 2005; Brem et al., 2008).

\section{Internal Control in SMEs}

SMEs have been classified into micro, small and medium-sized enterprises (Vietnamese Government, 2018). SMEs have a simple organizational structure, in which management tasks are integrated to optimize the use of resources. The investment capital of SMEs is relatively low and their production processes that create products and services are generally simple. Thus, the management structures of SMEs are flexible to change. In practice, SMEs' competitive advantages are as strong as large companies in many industries. Despite differences in organizational structures of SMEs and large companies, the internal control system of SMEs generally includes all components which are control environment, 
risk assessment, control activities, information and communication systems, and monitoring activities. In smaller entities, functions of the internal control system emphasize on cost-effectiveness, management override, monitoring activities, information technology, and board of directors (COSO, 2012).

In reality, SMEs shall establish a sound internal control to protect their assets and eliminate risks as well (Jiang \& Li, 2010). Internal control helps to prevent fraud in SMEs. In other words, internal control provides a reasonable assurance to meet SMEs' objectives. Internal control in SMEs showed its importance since it played a significant role in SMEs' operations (Uzun, 2011). Internal control plays a supporting role to assist organizations to reach their performance goals. A sound and effective internal control helps to improve corporate governance and eliminate risks in organizations (Shanmugam et al., 2012). IFAC indicated that possessing an effective internal control creates competitive advantages for business (IFAC, 2012) or sustains business growth (Wang \& Ding, 2019). In relation to internal control, an internal audit is crucial in most effective internal control systems to enhance the reliability of the reports and the responsibility of preparers and managers (Jensen, 2005).

Several scholars considered a limited number of internal control components for SMEs on the basis of SMEs' characteristics. Three important components were control environment, control activities, and monitoring of control (Nyakundi et al., 2014). In a survey research in Kenya, control activities, risk assessment, and information and communication were used to assess the influence of internal control on SMEs' financial performance. In several other studies, all components of internal control were independent variables in the regression of SMEs performance (Adegboyegun et al., 2020; Kamau, 2016).

\section{Relationship of Internal Control and Performance of SMEs}

Internal control has proved to have a significant role in the operations of SMEs (Kamau, 2016). The internal control system in an organization is designed to provide a reasonable assurance tool to reach SME's objectives. SME's objectives include operational effectiveness and efficiency, reporting reliability, and compliance with laws and regulations (COSO, 2012). Internal control has played an important role to raise SMEs' performance 
(Shanmugam et al., 2012). Therefore, internal control has been a sound and effective tool that has helped to improve corporate governance, to gain goals, and to eliminate risks (Kamau, 2016).

IFAC (2012) showed that internal control created competitive advantages since a company that has a sound internal control system would have a higher capability to cope with business risks. Internal control, generally, includes control environment, risk assessment, control activities, information and communication systems, and monitoring activities (COSO, 2012), while SME's performance was mainly influenced by monitoring activities, information and communication systems as indicated by (Kamau, 2016). The components of internal control certainly have impacts on financial and operational performance. The experiment confirmed the significant influence of internal control and performance in tertiary institutions (Akinleye \& Kolawole, 2019). Several elements of internal control had a positive impact on organizational success (Abiodun, 2020). The authors confirmed the relationship between internal control and performance in organizations but added additional information in their research model.

Kamau (2016) studied SMEs in Malaysia and confirmed the relationship between internal control and operations in SMEs. According to the financial view, internal control implementation had a significant impact on the outcome of SMEs. Besides, Malaysian SMEs in this study were willing to deploy internal control but the implementation was in the early stage. In the Malaysian case, almost all enterprises have had limited knowledge of and interest in internal control (Kamau, 2016). This is similar to the case of SMEs in Vietnam. Although in recent years, internal control has received attention from the management of SMEs, the effective of implementation is still in question in Vietnam.

Most studies on the relationship between internal control and performance have focused on financial or operational performance (Adegboyegun et al., 2020; Nyakundi et al., 2014; Odek \& Okoth, 2019). Several scholars have examined the impact of internal control on performance (Shanmugam et al., 2012; Kamau, 2016) and have attested to the influence of elements of internal control on performance. The study in Malaysia indicated that SMEs should enhance awareness of internal control 
(Shanmugam et al., 2012). These arguments lead to a conclusion that internal control, in general, has a significant impact on SMEs' performance.

In the survey of leaders and top managers of SMEs in previous studies (Adegboyegun et al., 2020; Nyakundi et al., 2014; Odek \& Okoth, 2019; Shanmugam et al., 2012; Suárez, 2016), internal control has proved its strong role to push SMEs' performance in developed and developing economies. In Vietnam, Thuy (2016) examined the impact of (internal) cost control on Vietnamese SMEs'performance. This study indicated the positive influence of internal control (included control environment, information and communication, risk assessment, and control activities) on the performance of manufacturing and business operations. Thus, it is essential to understand the impact of internal control on SME's performance in the context of Vietnam.

According to the theoretical framework and previous studies, this research examined the relationship of five elements of internal control (control environment, risk assessment, control activities, information and communication systems, and monitoring activities) on SMEs' performance (measured by ROA) in Vietnam.

\section{METHODOLOGY AND FINDINGS}

This research had used statistical techniques including a linear regression analysis to assess the impacts of internal control components on SMEs' performance.

\section{Research Model}

Learning from previous analysis, the research model is shown in Figure 1. The conceptual framework has been adopted mainly from the Agency Theory with references to the Contingency Theory and System Theory. Internal control, in the application of the Agency Theory, helps to reduce business risks resulting from asymmetric information between parties (Arwinge, 2012). The Contingency Theory indicates that a business was in good health and achieved its objectives, if it had an appropriate organizational structure and a good control environment (Jokipii, 2010; 
Bobkova, 2014). The System Theory has been a powerful tool to analyze the elements of internal control and the correlation of these elements in a systematic manner (Ayagre et al., 2014; Cheruiyot, 2014).

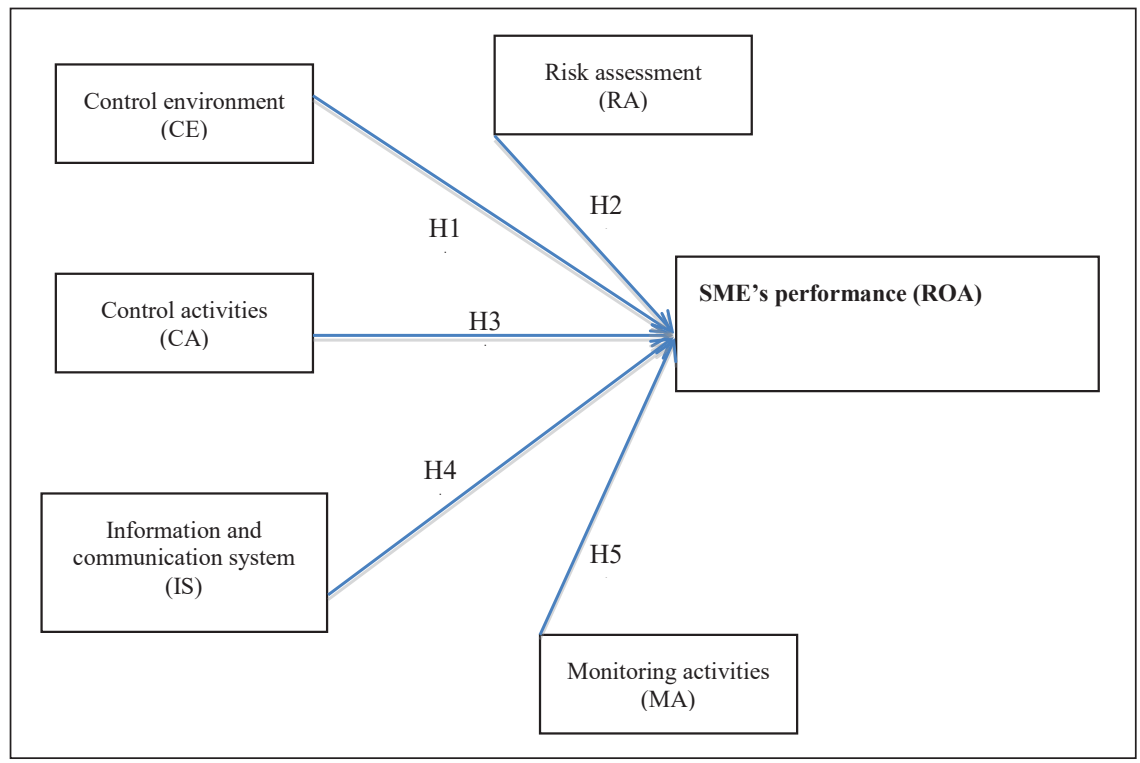

Figure 1: Research Model

On the basis of the theoretical framework that has been discussed previously, this study formulated the following hypotheses:

H1: Control enviroment positively affects SME's performance;

H2: Risk assessment positively affects SME's performance;

H3: Control activities positively affect SME's performance;

H4: Information and communication systems positively affect SME's performance;

H5: Monitoring activites positively affect SME's performance;

\section{Independent variables}

(1) Control environment (CE) was considered as a baseline for effective internal control. It is stated as an umbrella to support efficiency in every organization. Control environment in SMEs is measured by 5 items: Management's attitude and entity's management policies (CE1); Set the tone of the entity for control environment and influence an awareness 
of the control environment (CE2); Environment control affects the entire entity and all other internal control elements (CE3); Environment control assists to reduce fraud in the entity (CE4); Environment control enhances effective internal control (CE5)

(2) Risk assessment (RA) is another important component of internal control in SMEs: Risk assessment involved the identification and analysis of related risks (RA1); Risk assessment related to legal and financial risks (RA2); Risk assessment of maintaining a relevant risk level (RA3); Risk assessment with professional judgment about the likelihood and impact of risks (RA4); Risk assessment of identifying risks as a basis for management (RA5).

(3) Control activities (CA) included several indicators: Control activities apply complying policies and procedures in the organization properly (CA1); Control activities ensure necessary actions taken to address risks impacting an entity's objectives (CA2); Control activities describe the procedures and policies and best practices in SMEs to minimize risks (CA3), Control activities address risks to gain business objectives (CA4), Control activities are conducted with due care, responsibility, and consistency (CA5).

(4) Information and communication system (IS) were measured by 5 items as follows: Information and communication system support management and staffs to do their works (IS1), Information is a mean to recommend control procedures and policies (IS2), Communication helps employees to know managements' commitment to conduct internal control in an organization (IS3), Information is communicated to all people in the organization to conduct their responsibilities (IS4), Relevant and reliable information received from internal and external sources to communicate to all employees in the entity (IS5).

(5) Monitoring activities (MA) had several indicators: Monitoring activities including ongoing monitoring and separate evaluation (MA1), Monitoring activities indicating SME's best practice of self-auditing in the risk management system (MA2), Monitoring activities that help all employees comply with internal policies of the organization (MA3), Monitoring activities identifying the adequateness and effectiveness of the internal control system in the organization (MA4), Monitoring activities for the findings of audits or other reviews (MA5). 


\section{Dependent variables}

ROA is frequently used to measure SME's performance. Seens (2015) showed that SME's average ROA was generally in the range of $3.2 \%-3.9 \%$. In Vietnam during the year 2019, the deposit interest rate for a 12-month period had been in the range of $6.8 \%-7.5 \%$ (Vietnambiz, 2019, VCBS Research, 2019). Thus, this research assumed the rate of $7 \%$ as the average deposit interest rate representing the return for SMEs' owners in the case they just put their money in a bank. Therefore, the recommended rating scale for the ROA variable in this research was defined as follows:

Table 1: ROA scales

\begin{tabular}{llc}
\multicolumn{1}{c}{ ROA } & \multicolumn{1}{c}{ Scales } & Likert scale \\
\hline$<0 \%$ & Very inefficient & 1 \\
$0 \%-3 \%$ & Inefficient & 2 \\
$3 \%-4 \%$ & Moderate efficient & 3 \\
$4 \%-7 \%$ & Efficient & 4 \\
$>7 \%$ & Very efficient & 5 \\
\hline
\end{tabular}

Likert scales were used consistently for all items based on the previous studies.

\section{Sample Sizes}

There are several methods to estimate the appropriate sample size. Hair et al. (2014) suggested that the minimum sample size should be at least five times as many indicators in the model. As this model had 16 final indicators, we needed a sample size of at least 80 . Moreover, according to Cohen (1992), a sample size of 91 is appropriate for the SME's performance construct with five predictors (statistical power of $80 \%$, a level of 0.05 , and a medium effect size of 0.15 ). We had sent questionnaires using Google form and had received responses from 60 respondents. We got the other 34 responses from the Hanoi Planning and Investment department (excluded online responses). The survey period was from March to May 2019. A nonprobability sampling method which is the convenient sampling was used for this survey. The total useful data of 94 respondents satisfied the required data criterion. In our questionnaire, ROA was normalized into Likert scales as described in Table 1. 
We had cleaned the collected data and got 94 qualified responding data which could be used for analysis using the SPSS software and SmartPLS. Some factor indicators were excluded during the EFA analysis. Qualified indicators for PLS-SEM analysis included EC1, EC2, EC3 for control environment, AR1, AR4, AR5 for risk assessment, CP2, CP3 for control activities, AS 1, AS2, AS3, AS4 for information and communication system, and M1, M2. M3 for monitoring activities.

Table 2: Rotated Component Matrix ${ }^{a}$

\begin{tabular}{|c|c|c|c|c|c|}
\hline & \multicolumn{5}{|c|}{ Component } \\
\hline & 1 & 2 & 3 & 4 & 5 \\
\hline IS2 & 0.881 & & & & \\
\hline IS1 & 0.875 & & & & \\
\hline IS4 & 0.846 & & & & \\
\hline IS3 & 0.809 & & & & \\
\hline RA1 & & 0.853 & & & \\
\hline RA5 & & 0.826 & & & \\
\hline RA4 & & 0.824 & & & \\
\hline CE3 & & & 0.769 & & \\
\hline CE1 & & & 0.746 & & \\
\hline CE2 & & & 0.743 & & \\
\hline MA3 & & & & 0.815 & \\
\hline MA1 & & & & 0.780 & \\
\hline MA2 & & & & 0.681 & \\
\hline CA3 & & & & & 0.847 \\
\hline CA2 & & & & & 0.800 \\
\hline
\end{tabular}

\section{Results}

Data was analyzed using the SPSS and SmartPLS software. The SPSS was used for exploratory factor analysis (EFA) to confirm the appropriateness of factors and indicators (Hair et al., 2014). SmartPLS was used to assess the impact levels of factors in the research model. PLS-SEM has been frequently used to analyze complex linear structure models with a high reliability. Also, data does not need to meet the normally distributed criterion. 


\section{Descriptive statistics}

Most SMEs have run their business for under 15 years and most of them operated in the fields of service, commercial, and construction. The questionnaires had been sent to managers who were responsible for the financial functions of these SMEs.

Table 3: Classification of SMEs On the Basis of Operating Time

\begin{tabular}{lcc}
\hline \multicolumn{1}{c}{ Time } & Amount & $\%$ \\
\hline Under 5 years & 31 & $33 \%$ \\
From 5 to 10 years & 25 & $27 \%$ \\
From 10 to 15 years & 23 & $24 \%$ \\
From 15 to 20 years & 10 & $11 \%$ \\
Over 20 years & 5 & $5 \%$ \\
Total & $\mathbf{9 4}$ & $\mathbf{1 0 0 \%}$ \\
\hline
\end{tabular}

Table 4: Classification of SMEs On the Operating Field

\begin{tabular}{lcc}
\hline \multicolumn{1}{c}{ Business sector } & Amount & $\%$ \\
\hline Services business & 21 & $22 \%$ \\
Commercial business & 38 & $40 \%$ \\
Industrial manufacturing & 3 & $3 \%$ \\
Agricultural manufacturing & 7 & $7 \%$ \\
Construction business & 11 & $12 \%$ \\
Others & 14 & $15 \%$ \\
Total & $\mathbf{9 4}$ & $\mathbf{1 0 0} \%$ \\
\hline
\end{tabular}

\section{Regression analysis}

In PLS-SEM analysis, to ensure the validity of the latent variables, the outer loading of an indicator is preferred to be higher than 0.70 . If the outer loading of an indicator is between 0.4 and 0.7 , this factor can still be kept due to a specific condition given in (Hair et al., 2014). Indicators with outer loading lower than 0.40 were eliminated (Hair et al., 2014) (MA1 deleted). 
Table 5: Constructs and Indicators of The Model

\begin{tabular}{|c|c|c|c|c|c|}
\hline \multicolumn{2}{|l|}{ Constructs and indicators } & \multirow{2}{*}{$\begin{array}{c}\text { EFA } \\
\text { Loading }\end{array}$} & \multirow{2}{*}{$\begin{array}{l}\text { Loading } \\
\text { PLS-SEM }\end{array}$} & \multirow{2}{*}{ Mean } & \multirow{2}{*}{ Std. } \\
\hline Control environment (CE) & Cronbach's Alpha $=0.732$ & & & & \\
\hline \multicolumn{2}{|c|}{$\begin{array}{l}\text { Environment control affects the entire entity and all other } \\
\text { internal controls elements - CE3 }\end{array}$} & 0.769 & 0.670 & 4.117 & 0.697 \\
\hline \multicolumn{2}{|c|}{$\begin{array}{l}\text { Management's attitude and entity's management policies } \\
\text { - CE1 }\end{array}$} & 0.746 & 0.857 & 4.011 & 0.722 \\
\hline \multicolumn{2}{|c|}{$\begin{array}{l}\text { Set the tone of the entity for control environment and } \\
\text { influence the awareness of control environment - CE2 }\end{array}$} & 0.743 & 0.841 & 3.968 & 0.750 \\
\hline Risk assessment (RA) & Cronbach's Alpha $=0.830$ & & & & \\
\hline \multicolumn{2}{|c|}{$\begin{array}{l}\text { Risk assessment involves the identification and analysis } \\
\text { risks related - RA1 }\end{array}$} & 0.853 & 0.887 & 3.670 & 0.880 \\
\hline \multicolumn{2}{|c|}{ Risk assessment to identify risk basis for management - RA5 } & 0.826 & 0.871 & 3.628 & 1.010 \\
\hline \multicolumn{2}{|c|}{$\begin{array}{l}\text { Risk assessment with professional judgement about } \\
\text { likelihood and impact of risks - RA4 }\end{array}$} & 0.824 & 0.824 & 3.745 & 0.757 \\
\hline Control activities (CA) & Cronbach's Alpha $=0.713$ & & & & \\
\hline \multicolumn{2}{|c|}{$\begin{array}{l}\text { Control activities describe the procedures and policies and } \\
\text { best practice in SMEs to minimize risks - CA3 }\end{array}$} & 0.847 & 0.714 & 4.021 & 0.652 \\
\hline \multicolumn{2}{|c|}{$\begin{array}{l}\text { Control activities ensure necessary actions taken to address } \\
\text { risks impacted the entity's objectives - CA2 }\end{array}$} & 0.800 & 0.979 & 4.032 & 0.676 \\
\hline $\begin{array}{l}\text { I } n \text { form a } t \text { io } n \quad \text { a } n d \\
\text { communication system (IS) }\end{array}$ & Cronbach's Alpha = 0.899 & & & & \\
\hline \multicolumn{2}{|c|}{$\begin{array}{l}\text { Information is a means to recommend control procedures } \\
\text { and polices -IS2 }\end{array}$} & 0.881 & 0.913 & 4.064 & 0.848 \\
\hline \multicolumn{2}{|c|}{$\begin{array}{l}\text { Information and communication system support management } \\
\text { and staff to do their work - IS1 }\end{array}$} & 0.875 & 0.866 & 3.979 & 0.799 \\
\hline \multicolumn{2}{|c|}{$\begin{array}{l}\text { Information is communicated to all people in the organization } \\
\text { in order to conduct their responsibilities - IS } 4\end{array}$} & 0.846 & 0.922 & 4.053 & 0.690 \\
\hline \multicolumn{2}{|c|}{$\begin{array}{l}\text { Communication helps employees to have knowledge of their } \\
\text { managements' commitment to conduct internal control in the } \\
\text { organization - IS3 }\end{array}$} & 0.809 & 0.793 & 4.032 & 0.676 \\
\hline Monitoring activities (MA) & Cronbach's Alpha $=0.667$ & & & & \\
\hline \multicolumn{2}{|c|}{$\begin{array}{l}\text { Monitoring activities help all employees comply with the } \\
\text { internal policies of the organization - MA3 }\end{array}$} & 0.815 & 0.424 & 4.457 & 0.595 \\
\hline \multicolumn{2}{|c|}{$\begin{array}{l}\text { Monitoring activities included ongoing monitoring and } \\
\text { separated evaluation }\end{array}$} & 0.780 & 0.253 & 4.457 & 0.679 \\
\hline \multicolumn{2}{|c|}{$\begin{array}{l}\text { Monitoring activities indicates SME's best practice of self- } \\
\text { auditing in risk management system - MA2 }\end{array}$} & 0.681 & 0.995 & 4.309 & 0.758 \\
\hline SME's performance (ROA) & Cronbach's Alpha $=1.000$ & 1.000 & 1.000 & 2.851 & 1.110 \\
\hline
\end{tabular}




\section{Assessing the Validity and Reliability of Variables}

In the reflective measurement model, the reliability and validity of the construct are assessed according to the processing procedure introduced by (Hair et al., 2014). Main statistical criteria are included in the following tables:

1. Average Variance Extracted (AVE)

2. Composite Reliability

3. Cronbach's Alpha

4. Discriminant Validity

Table 6: Constructs' Reliability and Validity

\begin{tabular}{lccc}
\hline & $\begin{array}{c}\text { Cronbach's } \\
\text { Alpha }\end{array}$ & $\begin{array}{c}\text { Composite } \\
\text { Reliability }\end{array}$ & $\begin{array}{c}\text { Average } \\
\text { Variance } \\
\text { Extracted (AVE) }\end{array}$ \\
\hline $\begin{array}{l}\text { Risk assessment - RA } \\
\text { Information and }\end{array}$ & 0.830 & 0.896 & 0.741 \\
communication system - IS & 0.899 & 0.929 & 0.765 \\
Control activities - CA & 0.713 & 0.843 & 0.733 \\
Control environment - CE & 0.732 & 0.835 & 0.630 \\
Monitoring activities - MA & 0.566 & 0.729 & 0.604 \\
SME's performance - ROA & 1.000 & 1.000 & 1.000 \\
\hline
\end{tabular}

Hair et al. (2014) showed the composite reliability values between 0.70 and 0.90 can be regarded as satisfactory. Values above 0.95 are not desirable. All latent variables of the model were satisfactory. Cronbach's Alpha is acceptable with values higher than 0.60 (excepted for MA with Cronbach's Alpha $=0.566$ after MA1 deleted). The values of AVE should be higher than 0.50 . In this study, ROA was used as the sole performance indicator.

As shown in Table 7, all diagonal values (square root of AVEs) were higher than other values in the corresponding columns (cross-loadings), therefore, the discriminant validity was verified (Fornell \& Larker, 1981). 
Table 7: Discriminant Validity

\begin{tabular}{|c|c|c|c|c|c|c|}
\hline & $\begin{array}{c}\text { Risk } \\
\text { assessment }\end{array}$ & $\begin{array}{l}\text { Information and } \\
\text { communication } \\
\text { system }\end{array}$ & $\begin{array}{c}\text { Control } \\
\text { activities }\end{array}$ & $\begin{array}{c}\text { Control } \\
\text { environment }\end{array}$ & $\begin{array}{l}\text { Monitoring } \\
\text { activities }\end{array}$ & $\begin{array}{l}\text { SME's } \\
\text { performance }\end{array}$ \\
\hline $\begin{array}{l}\text { Risk } \\
\text { assessment }\end{array}$ & 0.861 & & & & & \\
\hline $\begin{array}{l}\text { Information } \\
\text { and } \\
\text { communication } \\
\text { system }\end{array}$ & 0.263 & 0.875 & & & & \\
\hline $\begin{array}{l}\text { Control } \\
\text { activities }\end{array}$ & 0.285 & 0.337 & 0.856 & & & \\
\hline $\begin{array}{l}\text { Control } \\
\text { environment }\end{array}$ & 0.374 & 0.267 & 0.311 & 0.794 & & \\
\hline $\begin{array}{l}\text { Monitoring } \\
\text { activities }\end{array}$ & 0.039 & 0.361 & 0.150 & 0.045 & 0.777 & \\
\hline $\begin{array}{l}\text { SME's } \\
\text { performance }\end{array}$ & 0.149 & -0.284 & -0.215 & 0.213 & -0.291 & 1.000 \\
\hline
\end{tabular}

Running the bootstrapping procedure (Hair et al., 2017) gave detailed results of the structural model.

Table 8: Results and Hypotheses Testing

\begin{tabular}{lcccc}
\hline \multicolumn{1}{c}{ Hypotheses } & b & t-Value & p-Value & Results \\
\hline $\begin{array}{l}\text { H1. Control environment positively } \\
\text { affects SME's performance }\end{array}$ & 0.299 & 3.013 & 0.003 & Confirmed \\
\hline $\begin{array}{l}\text { H2. Risk assessment positively affects } \\
\text { SME's performance }\end{array}$ & 0.183 & 1.587 & 0.113 & Not confirmed \\
\hline $\begin{array}{l}\text { H3. Control activities positively affects } \\
\text { SME's performance }\end{array}$ & -0.244 & 2.336 & 0.020 & Not confirmed \\
\hline $\begin{array}{l}\text { H4. Information and communication } \\
\text { systems positively affects SME's } \\
\text { performance }\end{array}$ & -0.265 & 3.041 & 0.002 & Not confirmed \\
$\begin{array}{l}\text { H5. Monitoring activities positively } \\
\text { affects SME's performance }\end{array}$ & -0.179 & 1.959 & 0.051 & Not confirmed \\
\hline
\end{tabular}

As the results in Table 8 shows only one hypothesis (H1) was confirmed, and the other hypotheses were rejected. This result confirms the significant impact of the control environment in organizations. Control activities, information and communication systems negatively affect SME's performance. This finding is similar to the result in the research of SMEs in the distribution industry in Kenya (Odek \& Okoth, 2019). The corresponding impact coefficients were -0.244 and -0.265 , respectively. In Vietnam SMEs, monitoring activities do not have a significant impact on financial performance. The $\mathrm{R}^{2}$ value of a latent variable in a model represents the percentage of the response variable variation that is explained by impact 
factors. The $\mathrm{R}^{2}$ value (0.271) of SME's performance in the model was not high, yet it still satisfied meaningful thresholds (Hair et al., 2017).

This study has several theoretical and practical implications on the relationship between internal control components and SMEs' financial performance. These are:

1. Control environment is the dominating factor in internal control that influences SMEs' performance. It has a pervasive effect on the whole entity and all the components of internal control. If the control environment did not have an impact, the confirmation of others' impacts would be meaningless in management. Furthermore, SMEs are generally dominated by the founders or CEOs who are strong and powerful to direct other personnel. This makes them tend to override established procedures. Therefore, SMEs should enhance the commitment to integrity and ethics, maintain the oversight of the implementation of internal control, ensure appropriate structures and reporting, authorities, and responsibilities, have relevant human policies, and concentrate on individual accountabilities through a performance measurement system. Thus, SME's internal control will meet a good practice with pervasive and significant influence on other elements in the entire entity.

2. Control activities and information and communication systems showed a negatively insignificant impact on SME's performance. The results suggest that SMEs' top management in this research do not pay enough attention to financial information systems. Currently, many SMEs have still used dual reporting systems, in which one report was used for official purposes and another used for internal monitoring. This may cause the lack of integrity of the reporting system which reduces the quality of financial information and increases the risk of misstatements. Besides, the results of a previous study (Kamau, 2016) had shown that control activities positively influenced performance. In SMEs, control activities have been executed ineffectively caused by the lack of sound policies and regulations within organizations. In the SMEs in Vietnam, the owners usually also play the role of the executives and they generally lack skills and knowledge for management. In SMEs, staffs are relatives of owners and managers, therefore management 
principles and policies are sometimes ignored. Although the findings of this paper indicated the negative influence of control activities and information and communication system, the best practice is usually integrated into five components of internal control (COSO, 2012). So, it is necessary to set-up control activities and information systems in an organization. This is important for each SME according to the developmental perspective in the long term. SMEs shall consider and design relevant activities and sound information and communication systems for monitoring the organizational operations. Therefore, SMEs' top management need to be equipped with the knowledge on control activities and information and communication systems to raise their assessment capabilities.

3. The hypothesis that risk assessment positively affects SME's performance was not confirmed. In SMEs, managers spent little time to assess risks which affected their businesses. SME's top managements usually pay high attention to the cost-benefit of setting-up internal control. Most of them thought that they knew the business risks and these risks are not important for their businesses. Practically, SMEs should seriously evaluate the potential risks and frauds that affected their objectives. They should find reasonable methods to eliminate risks or to keep the risks at acceptable levels. Knowledge of risk assessment (included possibility and impact) should be equipped for SMEs' top management.

4. Monitoring activities in SMEs seem neglected. The founders and CEOs of SMEs assume that their business activities are simple and should not be monitored closely. It leads to ineffective control of the business and inaccurate evaluation of other internal control elements.

\section{CONCLUSIONS AND RECOMMENDATIONS}

This research attests that to improve SMEs' performance, it is necessary to implement elements of internal control properly, in which the control environment is the most important one. SMEs in Vietnam should consider issues related to the control environment to improve the SMEs' performance. Theoretically, the paper reconfirmed the relationship of internal control 
and performance in enterprises, particularly in the SMEs environment. The results of this research support most results from the literature and the COSO model of internal control.

Control activities, information and communication system, risk assessment, and monitoring activities do not affect the performance of SMEs but the results from statistics can be useful for Vietnamese SMEs. Therefore, we recommend that SMEs pay attention to the application of internal control, risk knowledge or framework, control principles. SMEs should keep a higher commitment to integrity, ethical values, accountability, as well as the development of control activities through applying information technology, and relevant policies and procedures for operations. However, risk assessment, information and communication as well as monitoring activities should be organized systematically based on the real structure of each SME, to enhance the role of the internal control to cope with business risks in the current economy.

In addition to the research, the results as in Table 8 shows two relationships (Hypotheses $\mathrm{H} 3$ and $\mathrm{H} 4$ ) are significant but in the opposite sides. This suggests that, we need further research to explore these impacts detail. More researches should consider increasing the sample size to examine these hypotheses on a larger scale.

\section{REFERENCES}

Abiodun, E. A. (2020). Internal control procedures and firm's performance. International Journal of Scientific and Technology Research, 9(2), 6407-6415.

Adegboyegun, A. E., Ben-Caleb, E., Ademola, A. O., Oladutire, E. O., \& Sodeinde, G. M. (2020). Internal control systems and operating performance: Evidence from small and medium enterprises (SMEs) in Ondo state. Asian Economic and Financial Review, 10(4), 469-479.

Akinleye, G. T., \& Kolawole, A. D. (2020). Internal controls and performance of selected tertiary institutions in Ekiti state: A committee of sponsoring organisations (COSO) framework approach. International Journal of Financial Research, 11(1), 405-416. 
Aminu, I. M., \& Shariff, M. N. M. (2015). Determinants of SMEs performance in Nigeria: A pilot study. Mediterranean Journal of Social Sciences, 6(1), 156-156.

Arwinge, O. (2012). Internal control: A study of concept and themes. Springer Science \& Business Media.

Association of Chartered Certified Accountants (ACCA). (2016). Accountant in business (BPP Learning Media).

Asia Development Bank (ADB). (2020). Asia Small and Medium-Sized Enterprise Monitor 2020 - Volume I: Country and Regional Reviews. Retrieved from https://www.adb.org/publications/asia-sme-monitor2020-country-regional-reviews

Ayagre, P., Appiah-Gyamerah, I., \& Nartey, J. (2014). The effectiveness of internal control systems of banks. The case of Ghanaian banks. International Journal of Accounting and Financial Reporting, 4(2), 377-389.

Bobkova, N. G. (2014). Contingency theory and design of planning and control systems. Baikal International Business School. Irkutsk State University.

Brem, A., Kreusel, N., \& Neusser, C. (2008). Performance measurement in SMEs: Literature review and results from a German case study. International Journal of Globalisation and Small Business, 2(4), 411427.

Cheruiyot, S. K. (2014). Effectiveness of internal control systems in safeguarding inventory: A case study of Rift Valley Institute of Science and Technology (Master's thesis, Kabarak University).

Cohen, J. (1992). A power primer. Psychological Bulletin, 112(1), 155-159.

Committee of Sponsoring Organizations of the Treadway Commission (COSO). (2012). Internal control-integrated framework. 
Fornell, C., \& Larcker, D. F. (1981). Evaluating structural equation models with unobservable variables and measurement error. Journal of Marketing Research, 18(1), 39-50.

Hair, J. F., Black, W. C., Babin, B. J., \& Anderson, R. E. (2014). Multivariate data analysis ( $7^{\text {th }}$ ed.). Harlow: Pearson.

Hair, J. F., Hult, G. T. M., Ringle, C. M., \& Sarstedt, M. (2017). A primer on partial least squares structural equation modeling (PLS-SEM) $\left(2^{\text {nd }}\right.$ ed.). Thousand Oaks, CA: Sage.

Hussain, J., Millman, C., \& Matlay, H. (2006). SME financing in the UK and in China: A comparative perspective. Journal of Small Business and Enterprise Development, 13, 584-599.

International Federation of Accountants (IFAC). (2012). Evaluating and improving internal control in organizations. Retrieved from https:// www.ifac.org/about-ifac/professional-accountants-business/pu blications/evaluating-and-improving-internal-control-organizations- 0

Jensen, K. L. (2005). A basic study of agency-cost source and municipal use of internal versus external control. Accounting and Business Research, 35(1), 53-67.

Jiang, L., \& Li, X. (2010). Discussions on the improvement of the internal control in SMEs. International Journal of Business and Management, 5(9), 214-216.

Jokipii, A. (2010). Determinants and consequences of internal control in firms: A contingency theory based analysis. Journal of Management \& Governance, 14(2), 115-144.

Kamau, J. (2016). Effect of internal control practices on financial performance of small and medium enterprises in Nairobi County (Master's thesis, University of Nairobi).

Kokko, A., \& Sjöholm, F. (2005). The internationalization of Vietnamese small and medium-sized enterprises. Asian Economic Papers, 4(1), 152-177. 
Maelah, R., \& Yadzid, N. H. N. (2018). Budgetary control, corporate culture and performance of small and medium enterprises (SMEs) in Malaysia. International Journal of Globalisation and Small Business, 10(1), 77-99.

Nyakundi, D. O., Nyamita, M. O., \& Tinega, T. M. (2014). Effect of internal control systems on financial performance of small and medium scale business enterprises in Kisumu City, Kenya. International Journal of Social Sciences and Entrepreneurship, 1(11), 719-734.

Odek, R., \& Okoth, E. (2019). Effect of internal control systems on financial performance of distribution companies in Kenya. Research Journal of Finance and Accounting, 10(20), 11-32.

Organisation for Economic Co-operation and Development (OECD). (2019). Business insights on emerging markets 2019. OECD Emerging Markets Network. OECD Development Centre, Paris.

Pham, H. (2017). Determinants of new small and medium enterprises (SMEs) access to bank credit: Case study in the Phu Tho Province, Vietnam. International Journal of Business and Management, 12(7), 83-99.

Seens, D. (2015). SME operating performance (Research and Analysis Directorate, Small Business Branch Industry Canada).

Shanmugam, J. K., Haat, M. H. C., \& Ali, A. (2012). An exploratory study of internal control and fraud prevention measures in SMEs. International Journal of Business Research and Management, 3(2), 90-99.

Sharma, M. K., Bhagwat, R., \& Dangayach, G. S. (2005). Practice of performance measurement: Experience from Indian SMEs. International Journal of Globalisation and Small Business, 1(2), 183-213.

Suárez, C. A. (2016). Best management practices: SMEs' organizational performance management based on internal controls in Mexico. Journal of International Business and Economics, 4(2), 41-58. 
Thuan, P. Q. \& Cuong, N. C. (2020) Effectiveness of internal control in Vietnamese SMEs. Accounting and Auditing Journal (Vietnam), 5, 27-32.

Thuy, C. T. T. (2016). Internal control of production cost to enhance financial performance of small and medium-sized enterprise in Vietnam (tổ chức kiểm soát nội bộ chi phí sản xuất với việc nâng cao hiệu quả tài chính trong các doanh nghiệp nhỏ và vừa việt nam), Accounting and Auditing Institution (National Economics University).

Tran, T. C., Le., X. S. K., \& Nguyen, K. A. (2008). Vietnam's small and medium sized enterprises development: Characteristics, constraints and policy recommendations. In H. Lim (Ed.), SME in Asia and globalization (ERIA Research Project Report 2007-5).

Trinh, P. T. T., \& Thanh, N. D. (2017). Development characteristics of SME sector in Vietnam: Evidence from the Vietnam enterprise census 20062015. VEPR [Viet Nam Institute for Economic and Policy Research, supported by The Friedrich Naumann Foundation for Freedom] Working Paper WP-18. Hanoi, Vietnam.

Tuan, T. (2020). The effect of internal control on the performance of Vietnamese construction enterprises. Accounting, 6(5), 781-786.

Uzun, A. K. (2009, October). The Role of Internal Audit in Internal Control Quality in Corporate Organizations. In 3rd International Symposium on Auditing in Turkey, Istanbul (pp. 12-13).

VCBS Research (2019). Banking industry report 2019. Retrieved from https:// www.vcbs.com.vn/en/Communication/GetReport?reportId=6109

Vietnambiz (2019). Comparing deposit interest rate per yer in Vietnamese commercial bank in October 2019 (so sánh lãi suất ngân hàng kì hạn 1 năm mới nhất tháng 10/2019). Retrieved from https:// vietnambiz.vn/so-sanh-lai-suat-ngan-hang-ki-han-1-nam-moi-nhatthang-10-2019-20191007112023348.htm 
Vietnamese Government (2018). Decree 39/2018/nd-cp dated 11 March 2018 of detailed regulations of supporting small and medium - sized enterprises (Nghị định 39/2018/NĐ-CP, ngày 11/3/2018 về quy định chi tiết một số điều của luật hỗ trợ doanh nghiệp nhỏ và vừa), in Vietnam Government, ed.: Decree 39/2018/ND-CP.

Wang, L., Dai, Y., \& Ding, Y. (2019). Internal control and SMEs' sustainable growth: The moderating role of multiple large shareholders. Journal of Risk and Financial Management, 12(4), 182. 